\title{
籴槽晨漏症の研究
}

\section{歯 槽膿漏症について}

教授永。松幐海

私共が歯槽椣漏の研究するにあをり九州地区 連合菌科医師会より多額の補助蛽を頂昨年10 月その中間報告をなし今无、その研究結果を総 括して発表することが出来恋すてとを慗心よ 口、一同代代つて九州地区連合画科医師会の会 長初め役員各位亚江会員諸士に対して哚甚な感 謝の意を表明する炏第である。本研究は一応研 究唧告としては完結するが、な漂研究続行中の ものも亦るので、それ等は他日を期して公刊雑 誌任登表する予定である。

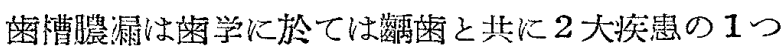

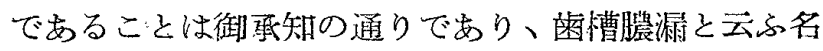
称を初めて用ひたのはトイラック・デジラボド（1946 年)であつた。それ以来 109 年後の今日に至るまで洋 の東西を閣はず諸学者に依つて、それぞれの專問に依 つて㮒及研究され且つ分䐝せられた。その数は枚举に 邀まない状態である。今充の分類の主なものを挙ぐれ ば次の通りである。

○逶牙附近組織炎（ホイプル氏による）

1）根端性宷不附近組織炎

2) 辺縁性歯牙附近組織炎

a) 表在㨫辺縁性柴牙附近組織炎

b）媣在性辺縁赀菌牙附近維織炎

○辺縁性迷可附近組織深虫(Weski 氏に上る 1921年)

(I) 全部性畨槽骨菱縮

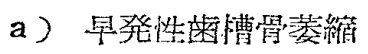

b）老人性㐘慒骨萎縮

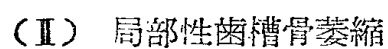

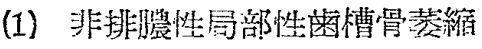

A 水西性继慒骨菱縮

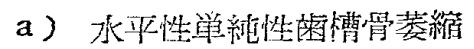

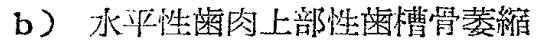

B 重淔性歯慒骨菱縮

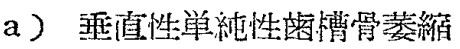

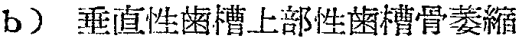

c）画直性蒾傮内部性菌槽骨菱維

（2）排膿性哥部性菌槽菱縮
A 水平性药蹧上部性脤淭
B 重直性歯慒骨萎縮

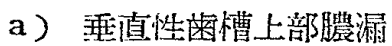

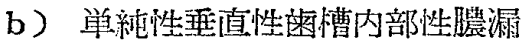

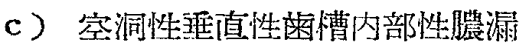

又 Kantrowicz-Sachs （カンッロウイッッ氏ー ザックス氏）は蒾慒膿漏を Paradentitis そ Paradentose とに分類した。

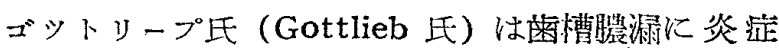
性々非炎泟性があるとして次の如く分類してるる。
A Schmutz Pyorroe (不䋜性膿漏)
B Pardetal Pyorroe (齿牙附近組織膿鼬)

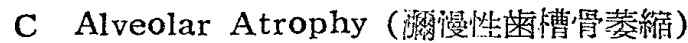

しかし、その後 Gottlieb 氏はこの分類を次のやう に砤めた。
(A) 化膿性辺縁性柴肉炎

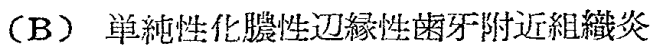

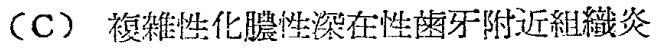
(D) 整耐骨栄養障碍症

Prinz (プリンッ氏1925年)

(A) Horizonal Pyorrea alveolaris

(B) Vertical Pyorrea alveolaris

(C) Precious diffuse Senile alveolar

\section{花沢鼎氏}

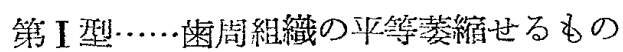

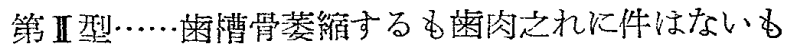

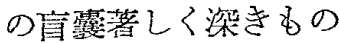




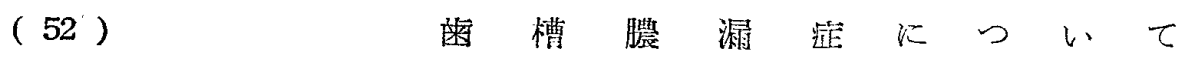

\section{第而型……溥肉增化せるるの}

第血型……歯慒骨の増生のむるもの.

その後正木正氏は急性発作榰型をこ机飞加光てる る。

\section{問田亮次氏}

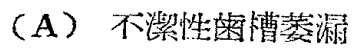
(B) 压迫性歯慒䑅厤

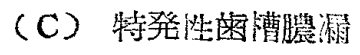
(D) 老人性菌膊膿溜
Chitron（ボトロン氏）
(A) 腦下垂体性楼慒膿淭

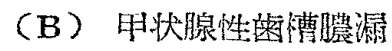
(C) 副时状腺性畨慒膿漏

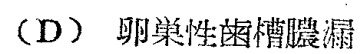

以上の如く諸学者俍つているいろの分数が行はれ

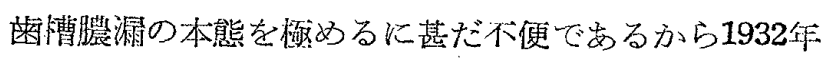

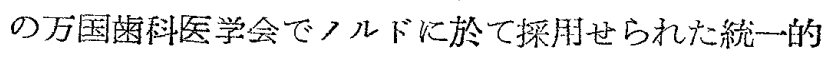
分類佉は次の通りである。

I 化膿性辺核性雷肉炎

II 宷可附近組織疾恝

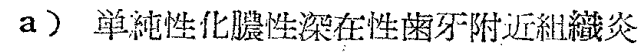

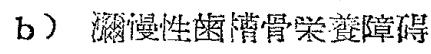

c). 䙉維性栄琴障碍性菌牙附近組織炎

\section{III娄慒骨萎縮}

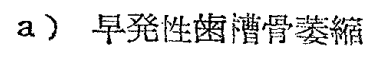

b）老人性:歯慒骨萎維

菡噌䟴漏の原因については現在次の如く信ぜられて るる。

（1）局所説 (2) 体筫説 (3) 合併説である。 な㴔病理学的䡴察から分粠すれば

(I) 外因的剌皇戈説
a) 米牙沈着物及び西石説
b) 感染説

c) 負担過重説

(II) 内因的刺㭜説
a) 新陳代謝障碍説
b) 内分爫機能哄常説
c) 易所栄筌神葓障碍説

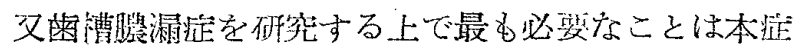
の証状でるるとは諭ずるまでるない。この三大主要 淽状は炏の道りである。

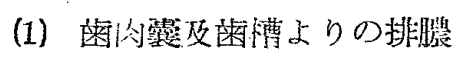

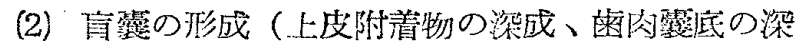
在)

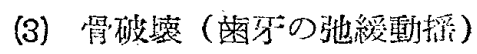

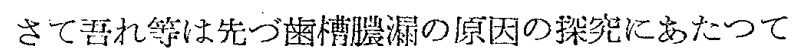

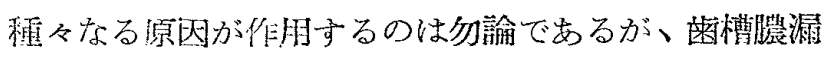
の主なる原因となるものは函肉部の上皮附責部の破鼠

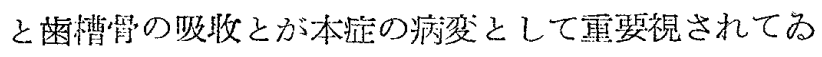
るのである。

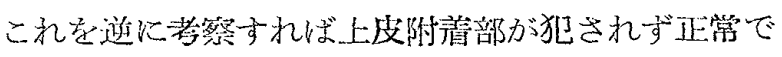

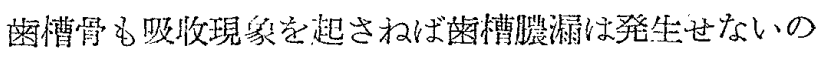
である。

因つて先つ”上皮附菁部を破㠃する石灭㨫泌着物、即

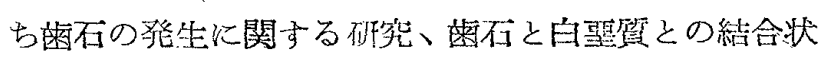

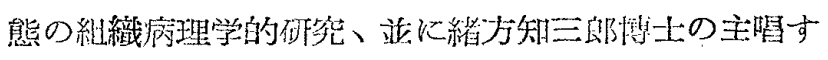

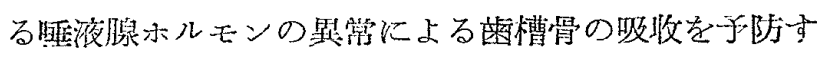

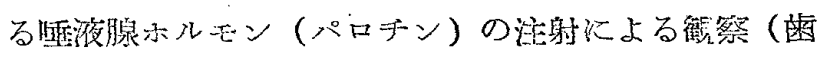
槽脿漏の治橑法）之私の耳下腺ホルモンの抽出とその

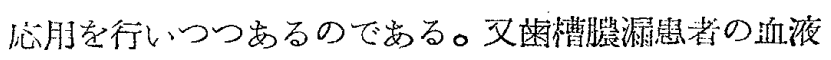

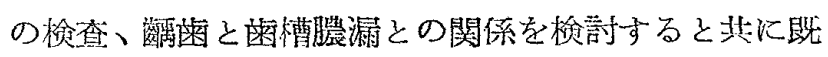

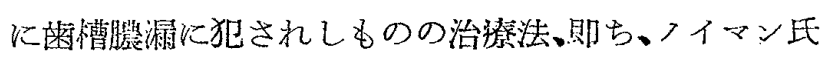
外科手術法の術後の治瘾㙨抎の研究雪肉切除法等の吴

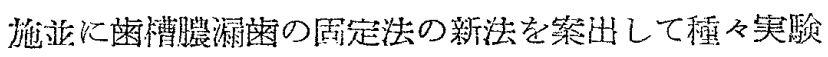
したそれぞれの砳究繥果をなさんとするのである。 